\title{
RARE METALS AND POLITICS
}

\begin{abstract}
Joanna TYSLER*
University of Gdansk, Faculty of Oceanography and Geography, Institute of Geography, Department of Regional Development, 8 Bażyńskiego Street, 80-309 Gdansk, Poland, e-mail: joatysler@gmail.com
\end{abstract}

Citation: Tysler, J. (2020). Rare Metals and Politics. Revista Română de Geografie Politică, 22(1), 38-47. https://doi.org/10.30892/rrgp.221105-338

\begin{abstract}
Rare earth elements are a collection of 17 elements, which include lanthanides and scandals. They are used to make many devices - from electronics to the defense industry. Currently, China is the largest producer of these raw materials, although deposits of these elements are also found in other countries, e.g. United States of America or Japan. Although the name suggests otherwise, metal deposits are abundant in the world. The problem is their extraction and concentration of individual minerals, resulting from the chemical structure.
\end{abstract}

Key words: rare earth elements, rare earth metals, ores, resources, demand

\section{INTRODUCTION}

Rare earth metals, also known as REE (rare earth elements), are a group of 17 elements, which include lanthanides and scandals. This group includes elements with atomic numbers from 57 to 71 (15 lanthanides: La - Lanthanum, $\mathrm{Ce}$ - Cerium, Pr - Praseodymium, Nd - Neodymium, Pm - Promethium, Sm Samarium, Eu - Europium, Gd - Gadolinium, Tb - Terbium, Dy - Dysprosium, Ho - Holmium, Er - Erbium, Tm - Thulium, Yb - Ytterbium, Lu - Lutetium) and 21 and 39 atomic scandals (Sd - Scandium, Y - Yttrium), which have similar chemical properties (figure 1) (Hedrick, 1997).

These elements belong to the group of rock-loving elements - they concentrate mainly in the Earth's crust. They are also incompatible, which means that during the transformation of rocks or crystallization of magma they accumulate in the liquid phase - the alloy. This feature decreases with the ionic radius from cerium to lutetium.

REE are characterized by high chemical activity. This results in occurrence in natural conditions only in the form of salts - carbonates, phosphates, silicates or oxides, occurring in associations with other metals (Castor and Hedrick, 2006).

Contrary to popular judgment and name, these elements do not occur in nature rare. The problem is their distribution and concentration. This is due to their atomic structure and geochemical properties. Elements with even atomic 
numbers are more common on Earth than those with odd atomic numbers. Similarly, lighter rare earth elements (LREE) have a larger ion radius, which translates into less frequent substitution with other elements. They also show a greater tendency to occur in mineral phases than the heavier rare earth elements - HREE (occurring from Gd to Lu) (table 1).
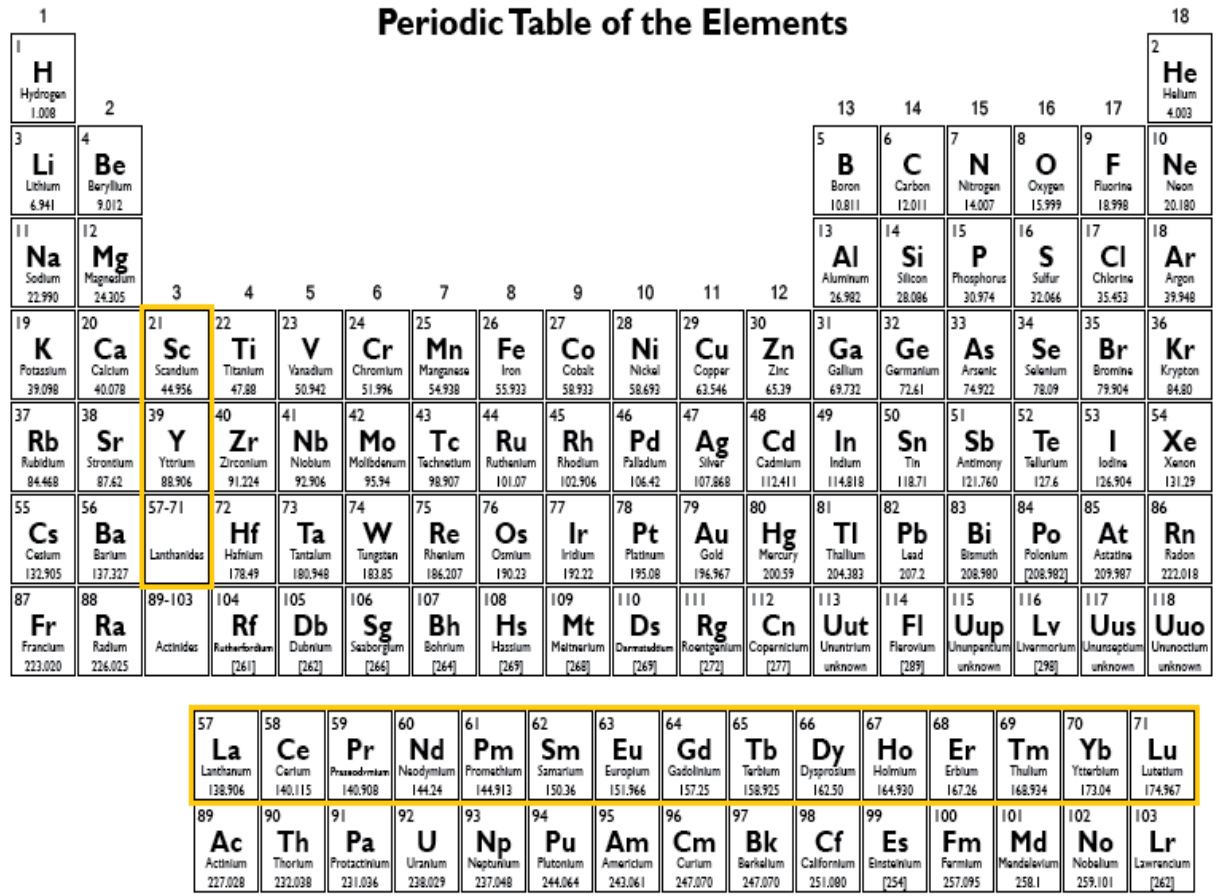

Figure 1. Periodic Table of elements 1

Table 1. Light and Heavy rare earth elements

(Source: UNCTAD Secretariat from the British Geological Survey)

\begin{tabular}{|c|c|c|c|}
\hline Atomic number & Name & Symbol & LREE / HREE \\
\hline 57 & Lanthanum & $\mathrm{La}$ & LREE \\
\hline 58 & Cerium & $\mathrm{Ce}$ & LREE \\
\hline 59 & Praseodymium & $\mathrm{Pr}$ & LREE \\
\hline 60 & Neodymium & $\mathrm{Nd}$ & LREE \\
\hline 61 & Promethium & $\mathrm{Pm}$ & LREE \\
\hline 62 & Samarium & $\mathrm{Sm}$ & LREE \\
\hline 63 & Europium & $\mathrm{Eu}$ & LREE \\
\hline 64 & Gadolinium & $\mathrm{Gd}$ & LREE \\
\hline 65 & Terbium & $\mathrm{Tb}$ & HREE \\
\hline 66 & Dysprosium & $\mathrm{Dy}$ & HREE \\
\hline 67 & Holmium & $\mathrm{Ho}$ & HREE \\
\hline 68 & Erbium & $\mathrm{Er}$ & HREE \\
\hline 69 & Thulium & $\mathrm{Tm}$ & HREE \\
\hline 70 & Ytterbium & $\mathrm{Yb}$ & HREE \\
\hline 71 & Lutetium & $\mathrm{Lu}$ & \\
\hline 39 & Yttrium & $\mathrm{Y}$ & \\
\hline 21 & Scandium & $\mathrm{Sc}$ & \\
\hline & & & \\
\hline
\end{tabular}


The characteristic features of rare earth metals include: high dispersion, no occurrence in pure metallic form, the rarity of creating own minerals visible to the human eye (Porowski and Kaczor-Kurzawa, 2016).

\section{PRESENCE IN THE WORLD}

There are more than 250 REE minerals known in the world, but only some of them are important for industry. In table 2 the most important of them are presented. They are most often found in the lithosphere in the form of fluorocarbonates, phosphates and silicates.

Table 2. Main minerals containing REE

Source: Ln - lanthanides group, REO - rare earth oxides (Zhang et al., 2016

\begin{tabular}{|c|c|c|}
\hline Mineral & Chemical formula & Content of REO (\%) \\
\hline Bastnaesite & $\mathrm{LnCO}_{3} \mathrm{~F}$ & 74,8 \\
\hline Monazite & $(\mathrm{Ln}, \mathrm{Th}) \mathrm{PO}_{4}$ & 65,1 \\
\hline Xenotime & $\mathrm{YPO}_{4}$ & 62,0 \\
\hline Fluocerite & $(\mathrm{Ce}, \mathrm{La}) \mathrm{F}_{3}$ & 83,4 \\
\hline Parisite & $\mathrm{CaLn}_{2}\left(\mathrm{CO}_{3}\right)_{3} \mathrm{~F}_{2}$ & 60,3 \\
\hline Fergusonite & $\mathrm{YNbO}_{4}$ & 39,9 \\
\hline Gadolinite & $\mathrm{Y}_{2} \mathrm{FeBe}_{2} \mathrm{Si}_{2} \mathrm{O}_{10}$ & 48,3 \\
\hline Aeschynite & $(\mathrm{Y}, \mathrm{Ca}, \mathrm{Fe})(\mathrm{Ti}, \mathrm{Nb})_{2}(\mathrm{O}, \mathrm{OH})_{6}$ & 24,6 \\
\hline Euxenite & $(\mathrm{Y}, \mathrm{Ca}, \mathrm{Ce})(\mathrm{Nb}, \mathrm{Ta}, \mathrm{Ti})_{2} \mathrm{O}_{6}$ & 24,3 \\
\hline Synchysite & $\mathrm{Ca}(\mathrm{Y}, \mathrm{Ce})\left(\mathrm{CO}_{3}\right)_{2} \mathrm{~F}$ & 49,6 \\
\hline Samarskite & $(\mathrm{Y}, \mathrm{Fe}, \mathrm{U})(\mathrm{Nb}, \mathrm{Ta})_{5} \mathrm{O}_{4}$ & 24,3 \\
\hline Polycrase & $(\mathrm{Y}, \mathrm{Ca}, \mathrm{Ce}, \mathrm{U}, \mathrm{Th})(\mathrm{Ti}, \mathrm{Nb}, \mathrm{Ta})_{2} \mathrm{O}_{6}$ & 19,5 \\
\hline Loparite & $(\mathrm{Ce}, \mathrm{NaCa})_{2}(\mathrm{Ti}, \mathrm{Nb})_{2} \mathrm{O}_{6}$ & 29,8 \\
\hline
\end{tabular}

The content of rare earths in the lithosphere is very diverse and depends mainly on the type of rock and its origin. The content of REE is generally in the range of 0,1 to $100 \mathrm{mg} / \mathrm{kg}$. For example, in riolites and granites, there is a higher concentration of these metals than in basalt. Likewise, clays and shales contain more REE than limestone and sandstone. In addition, LREE content in rock ores is generally greater than HREE. In table 3 the number of rare earths is given (Porowski and Kaczor-Kurzawa, 2016).

Table 3. Abundance of REE in in the Earth's crust in parts per million

(Source: Moran-Palacios et al., 2019)

\begin{tabular}{|c|c|c|c|c|c|c|c|c|}
\hline Element & $\begin{array}{c}\text { Kleber } \\
\text { and } \\
\text { Love } \\
(\mathbf{1 9 6 3 )}\end{array}$ & $\begin{array}{c}\text { Ryan } \\
\mathbf{( 1 9 6 8 )}\end{array}$ & $\begin{array}{c}\text { Jackson and } \\
\text { Christiansen } \\
\mathbf{( 1 9 9 3 )}\end{array}$ & $\begin{array}{c}\text { Wedepohl } \\
\mathbf{( 1 9 9 5 )}\end{array}$ & $\begin{array}{c}\text { Sabot } \\
\text { and } \\
\text { Maestro } \\
(\mathbf{1 9 9 5}\end{array}$ & $\begin{array}{c}\text { McGill } \\
\mathbf{( 1 9 9 7 )}\end{array}$ & $\begin{array}{c}\text { Lide } \\
\mathbf{( 1 9 9 7 )}\end{array}$ & $\begin{array}{c}\text { Earth } \\
\text { Crust } \\
\text { (ppm) }\end{array}$ \\
\hline $\mathrm{Sc}$ & 10 & - & - & 16 & 10 & $5-10$ & 22 & \\
\hline $\mathrm{Y}$ & 28 & - & 29 & 24 & 28 & $28-70$ & 33 & \\
\hline $\mathrm{La}$ & 18 & 18,3 & 29 & 30 & 18 & $5-18$ & 39 & 30 \\
\hline $\mathrm{Ce}$ & 46 & 46,1 & 70 & 60 & 46 & $20-46$ & 66,5 & 60 \\
\hline $\mathrm{Pr}$ & 5,5 & 5,53 & 9 & 6,7 & 5,5 & $3,5-5,5$ & 9,2 & 6,7 \\
\hline $\mathrm{Nd}$ & 24 & 23,9 & 37 & 27 & 24 & $12-24$ & 41,5 & 27 \\
\hline $\mathrm{Sm}$ & 6,5 & 6,47 & 8 & 5,3 & 6,5 & $4,5-6,4$ & 7,05 & 5,3 \\
\hline $\mathrm{Eu}$ & 0,5 & 1,06 & 1,3 & 1,3 & 0,5 & $0,14-1,1$ & 2 & 1,3 \\
\hline $\mathrm{Gd}$ & 6,4 & 6,36 & 8 & 4 & 6,4 & $14,5-6,4$ & 6 & 4 \\
\hline $\mathrm{Tb}$ & 0,9 & 0,91 & 2,5 & 0,7 & 0,9 & $0,7-1$ & 1,2 & 0,7 \\
\hline $\mathrm{Dy}$ & 5 & 4,47 & 5 & 3,8 & 5 & $4,5-7,5$ & 5,2 & 3,8 \\
\hline $\mathrm{Ho}$ & 1,2 & 1,15 & 1,7 & 0,8 & 1,2 & $0,7-1,2$ & 1,3 & 0,8 \\
\hline $\mathrm{Er}$ & 4 & 2,47 & 3,3 & 2,1 & 4 & $2,5-6,5$ & 3,5 & 2,1 \\
\hline $\mathrm{Tm}$ & 0,4 & 0,2 & 0,27 & 0,3 & 0,4 & $0,1-1$ & 0,52 & 0,3 \\
\hline $\mathrm{Yb}$ & 2,7 & 2,66 & 0,33 & 2 & 2,7 & $2,7-8$ & 3,2 & 2 \\
\hline $\mathrm{Lu}$ & 0,8 & 0,75 & 0,8 & 0,7 & 0,8 & $0,8-1,7$ & 0,8 & 0,7 \\
\hline
\end{tabular}


About $67 \%$ of the world's resources occur in three regions: China, which has $31 \%$ of the resources of various types - bastnaesite (Sichuan and Inner Mongolia), laterite clays (Jiangxi) and monacite black beach sands. In Russia, there is $21 \%$ of the world's stocks of shovel, while in the USA - $15 \%$, mainly bastnaesite and monacite. Australia also has small ore deposits - 6\% (monocyte crumb deposits), and Canada and India 1\% each (Smakowski et al., 2015).

Other sources of rare earth metals are xenimime ores, found in Malaysia and Thailand, phosphorites, apatites, eudialite and waste of uranium solutions, located in Kazakhstan and Russia (Smakowski et al., 2015).

Data on the volume of global rare earths resources vary quite significantly. According to Smakowski et al., they amount to 88 million tons of $\mathrm{Ln}_{2} \mathrm{O}_{3}$. In turn, Całus-Moszko and Białecka (2012) estimate them at about 110 million tons.

\section{PRODUCTION}

Rare earths are usually obtained from three types of ores: bastnaesite (USA, China), monacite (China, USA, Australia, Brazil, India, Malaysia, Sri Lanka and Thailand) and laterite. The first stage in the production of rare earths is the extraction of ore using standard mining methods. The ore was mined for gravel. It continues to crumble until small fractions of rock are obtained. Further, the crushed ore is placed in a tank, where individual metals attach to the bubbles of admitted air in the filtration process. Rare earths are obtained by using various chemicals. The process is used until pure elements are obtained in the form of oxides (Hurst, 2010).

The demand for rare earths is constantly increasing. In 1950 it was about than 100 tons / year. In 1990 it increased to 40,000 tons per year. In 2000 it amounted to around 80,000 tonnes and now - over 200,000 tonnes (Wyłuda, 2016). ${ }^{2}$

Prior to 1965, the demand for rare earths was relatively low. At that time, most of the world's supplies were produced from crumb deposits in India and Brazil. In the 1950s, South Africa became a leading producer of mazite deposits containing rare earths. At that time, the Mountain Pass Mine in California produced small amounts of rare earth oxides from Precambrian carbonate. ${ }^{3}$

The demand for rare earths first exploded in the mid-1960s, when the first color televisions went on sale. Europium was a necessary raw material to produce color images (figure 2).

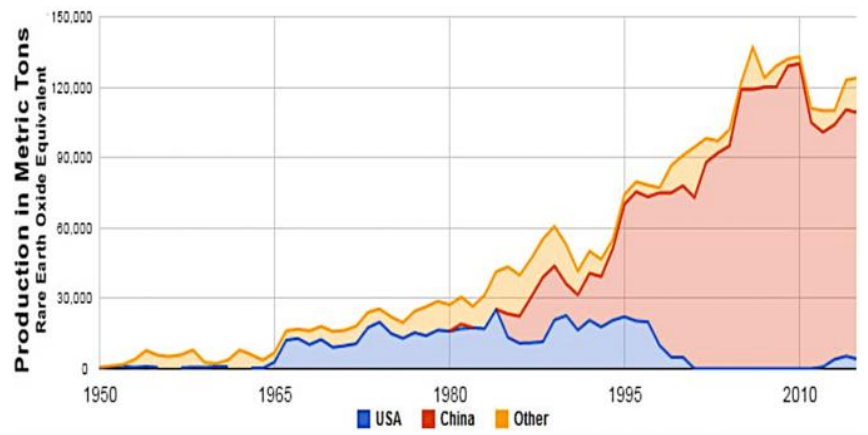

Figure 2. Production of rare earth elements (Source: chemical-materials.elsevier.com)

\footnotetext{
${ }^{2}$ https://www.edukacjagieldowa.pl/2016/09/cenniejsze-niz-zloto-diamenty-metale-ziem-rzadkich/

${ }^{3}$ https://poltimes.pl/metale-ziem-rzadkich-strategiczne-surowce-w-rekach-chin/
} 
At the Mountain Pass Mine, production of europium from bastnaesite began, which contained about $0,1 \%$ of europium. As a result, the Mountain Pass Mine has become the largest producer of rare earths in the world, and the United States has become a leading producer (Lifton, 2010).

In the early 1980s, China began producing significant amounts of rare earth oxides. They became a world leader in the early 1990s. In the 1990s and early 2000, China successively strengthened its importance in the world economy of rare earth oxides. Prices of Chinese rare earths were so low that Mountain Pass Mine and many others around the world were unable to compete and stopped functioning (Hurst, 2010).

At the same time, global demand has risen sharply because rare earths have been used in the production of safety, aviation and automotive components, industry and consumer electronics (figure 3).

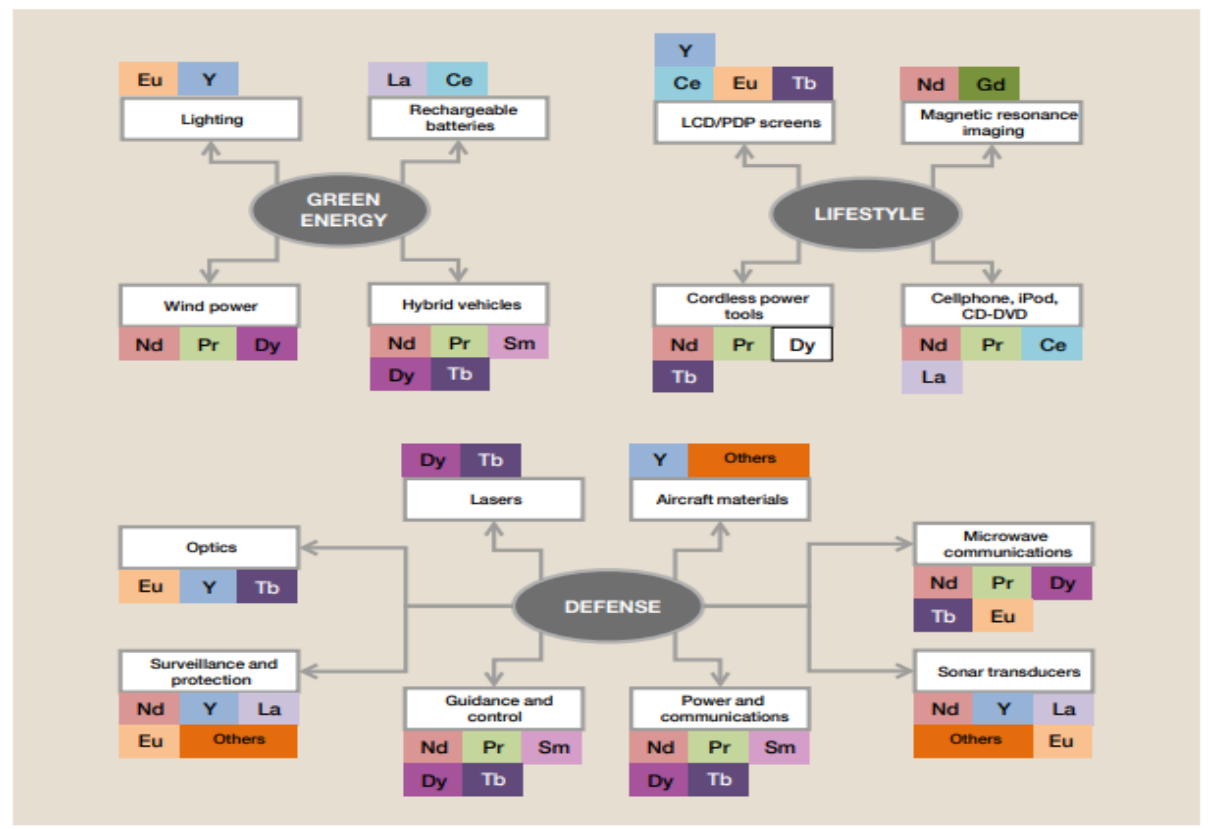

Figure 3. Sectors using REE

(Source: UNCTAD Secretariat from Great Western Minerals Group Ltd)

China has used its dominance and began to restrict exports and made the rare earth oxides prices reached the highest level ever (figure 4) (Morrison et al., 2012). ${ }^{4}$ China's Rare Earth Industry and Export Regime: Economic and Trade Implications for the United States. Congressional Research Service).

Apart from being the world's largest producer of rare earths, China is also the largest consumer (figure 5). China uses REE primarily to produce electronic products for domestic and foreign markets. Japan and the United States are the next largest consumers of the elements. To protect the added value of their manufacturing sector, China is reluctant to sell rare earths. 5

\footnotetext{
${ }^{4}$ http://www.fas.org/sgp/crs/row/R42510.pdf

${ }^{5}$ https://independenttrader.pl/metale-ziem-rzadkich-marginalizowane-aktywo.html
} 


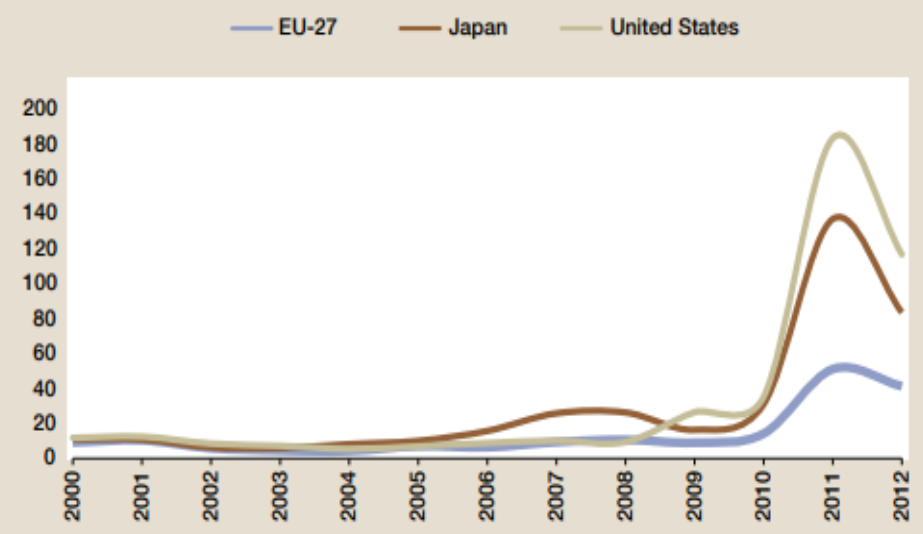

Figure 4. Changes of unit value of rare earth imports in 2000-2012 (US\$ per kilo) (Source: UNCTAD Secretariat from UN COMTRADE (HS 2012: 280530))

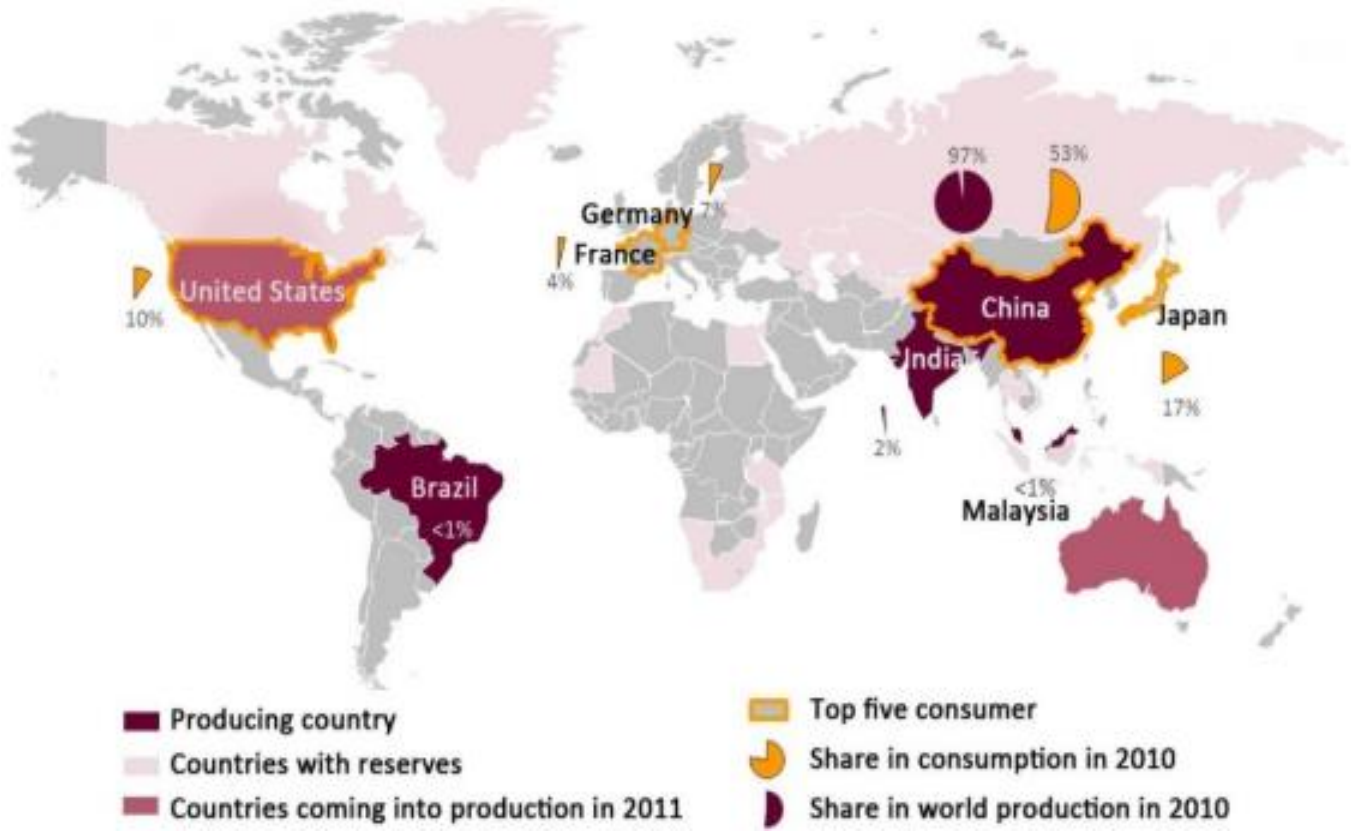

Figure 5. Map of global producers and consumers of REE 6

The climax of Chinese domination could have occurred in 2010, when China oversaw around $95 \%$ of world production of rare earth metals. This was a stimulus for mining companies in the United States, Australia, Canada and other countries that began to reassess old prospects for rare earths and seek new ones. High prices led manufacturers to take three steps (Pourmand et al., 2012):

- looking for ways to reduce the amount of rare earths used to make each of their products;

- looking for alternative materials that replace rare earths;

- develop variant products that do not need rare earths.

\footnotetext{
${ }^{6}$ https://ecowasterecycling.wordpress.com/
} 
Chinese companies buy rare earths in other countries. In 2009, the China NonFerrous Metal Mining Company acquired the majority of shares in the Australian company Lynas Corporation, which has one of the highest rare earths production outside China. They also bought the Baluba Mine in Zambia (Kelly, 2009).

In 2011, Australian Mines began producing rare earth oxides. In 2012 and 2013, they were covering around 2-3\% of global demand. In 2012, the Mountain Pass Mine returned to production, and in the United States in 2013, about 4\% of the world's rare earths was produced. Manufacturing in Brazil, Malaysia, Russia, Thailand and Vietnam remained stable or increased (Zamęcki, 2011).

Recently, the United States Geological Survey has identified significant resources outside China. Although China is dominant in the production of rare earth metals, they merely superintend about $36 \%$ of global resources. This gives other countries the chance to become important manufacturers, when China doesn't want to sell rare earth metals below production costs. 78

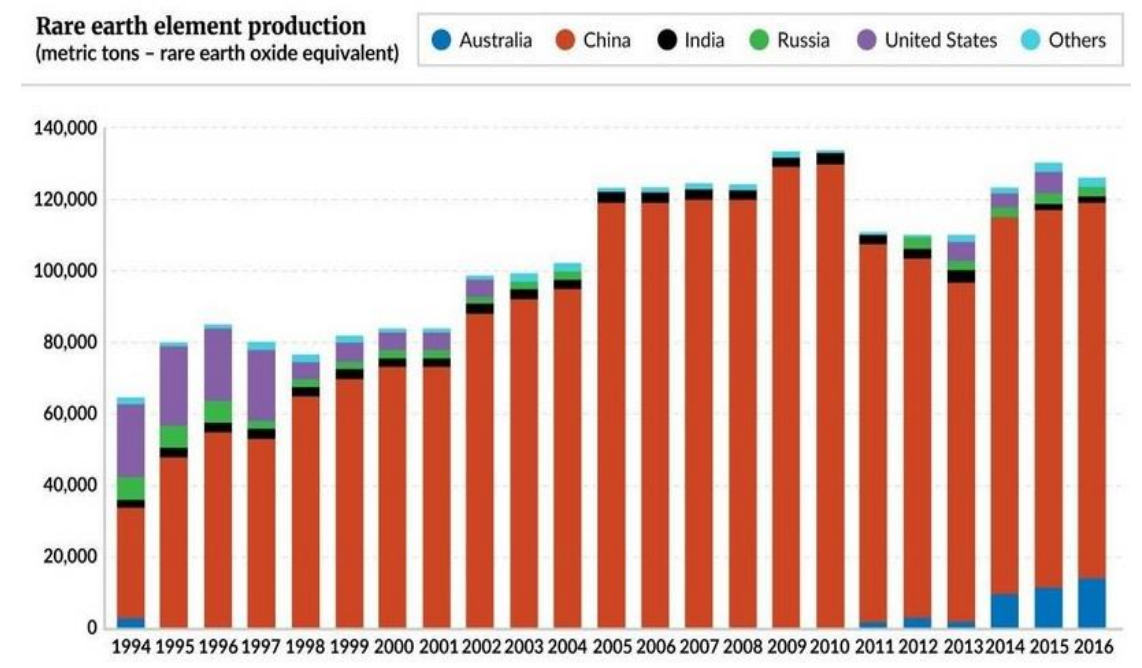

Figure 6. Production of REE by country in 1994-2016 (Source: European Comission/Transport\&Environment 2017) ${ }^{9}$

The figure 6 shows the dominance of China in the production of rare earths in the years 1994-2016. The United States was an important manufacturer until the 1990s, but cheap materials being sold by China forced the withdrawal of mines in the United States and other countries. Because China has reduced exports and prices have risen sharply in 2009 and 2010, Australian and US mines have started operating again. The Chinese government explained that this was done to guarantee the supply of rare earths for domestic production and for environmental reasons. This change generated by China has caused panic, and some rare earth prices have risen significantly. Furthermore, Japan, the United States and the European Union filed to the World Trade Organization about China's restrictive trade policiesof rare earth elements (Kalantzakos, 2017).

\footnotetext{
${ }^{7}$ http://www.marketwatch.com/story/molycorp-strikes-rare-earth-elements-in-california-2011-10-04

${ }^{8}$ http://online.wsj.com/article/SB10001424052970204612504576609413994133684.html

${ }^{9}$ www.GISreportsonline.com
} 


\section{CURRENT SITUATION}

The demand for rare earths is higher than supply. Due to the everincreasing demand, it is not known whether producers will be able to increase production before stocks run out. According to OECD forecasts, the demand for rare earths in 2060 is expected to increase to $19 \mathrm{Gt} /$ year. 10

By introducing export restrictions (including hindering the export of elements from the country), China has strengthened its position in the world. The government explains these restrictions by increasing internal consumption and protecting the environment. Through previous state policy - a prosperous mining industry, low labor costs, a lack of environmental standards and unlicensed mining and processing, China has led to a monopoly on mining.

Although Japan has discovered large deposits of rare earths, it is not known whether the balance of power will change. According to the forecasts, 1 $\mathrm{km}^{2}$ metals from Japanese deposits could satisfy $20 \%$ of the current demand of the raw material. However, mining is a problem. The deposits are located at the bottom of the Pacific Ocean at a depth of 3500 to $6000 \mathrm{~m}$. Until the Japanese start exploiting the deposits, China will continue to use the current situation to exert pressure and negotiate commercial transactions (Błoński, 2011).

Currently in the United States, in California, it operates one ore mine rare earth metals. Mined rocks, however, are sent for processing to China, which is subject to a $25 \%$ duty. As a result, China covers $80 \%$ of the US demand for rare earths. Suspending supplies would pose a real threat to the US economy. Without them, it is impossible to produce computers, military equipment or electric / hybrid cars. The real threat of the trade war on the Washington-Beijing line was exacerbated last year by cutting off the Chinese group Huawei from American technology. ${ }^{11} 1213$

\section{CONCLUSION}

Currently, rare earth metals are gaining significant significance for economic development, in addition to oil and natural gas. Without their use, many inventions of modern technologies would look completely different, and others would not exist at all. Rare earth metals are a key component of advanced military and civilian devices, as well as a key element in the use of green technologies such as wind turbines and hybrid cars. 97 percent of rare earths are currently produced in China. However, the growing global demand as well as Chinese export restrictions raise concerns of international corporations as to maintaining supply continuity. Situations are additionally hindered by China's increasing domestic demand.

Global governments, scientists and industry looking for new solutionsextraction, recycling or substitution, but for now it is not enough. Newly discovered deposits are not able to cover the growing demand of the world. For now, China's conditions should be accepted, but alternatives should be sought out.

\section{Aknoledgments}

The author wished to thank Professor J.A. Wendt for his helpful comments an earlier drafts of this paper.

\footnotetext{
${ }^{10}$ https://www.spidersweb.pl/2019/07/zapotrzebowanie-na-metale-ziem-rzadkich-elektronika-gornictwo-kosmiczne.html

${ }^{11}$ https://klubjagiellonski.pl/2019/08/14/metale-ziem-rzadkich-oczko-w-glowie-chinskiej-republiki-ludowej/\#

${ }^{12}$ https://forsal.pl/artykuly/1414979,metale-ziem-rzadkich-nowym-orezem-w-walce-chin-z-usa.html

${ }^{13}$ https://www.wnp.pl/tech/chca-zaspokoic-zapotrzebowanie-na-metale-ziem-rzadkich,346568.html
} 


\section{REFERENCES}

Błoński, M. (2011). Odkryto kolosalne złoża metali ziem rzadkich, http://kopalniawiedzy.pl/metaleziem-rzadkich-zloza-Ocean-Spokojny-13392.html

Całus Moszko, J., \& Białecka, B. (2012). Potencjał i zasoby metali ziem rzadkich w świecie oraz w Polsce. Artykuł przeglądowy. Prace Naukowe GIG. Górnictwo i Środowisko/Główny Instytut Górnictwa.

Castor, S.B., Hedrick, J.B. (2006). Rare Earth Elements. [W:] Kogel, J.E.,Trivedi, N.C., Barker, J.M., Krukowski, S. (eds), Industrial Minerals and Rocks - Commodities, Markets, and Uses. Society for Mining, Metallurgy, and Exploration (SME), 769-792 s.

Hedrick, J. B. (1997). Rare-earth metal prices in the USA ca. 1960 to 1994. Journal of Alloys and Compounds, 250(1-2), 471-481.

Hurst, C. (2010). China's rare earth elements industry: What can the west learn?. Institute for the Analysis of Global Security Washington DC.

Jackson, W. D., \& Christiansen, G. (1993). International Strategic Minerals Inventory Summary Report--rare-earth Oxides (No. 930). US Government Printing Office.

Kalantzakos, S. (2017). China and the geopolitics of rare earths. Oxford University Press.

Kelly, R. (2009). Australia Delays Ruling on China Rare-Earth Investment, http://chinhdangvu.blogspot.com/2009/09/australia-delays-ruling-on-china-rare.html

Lide, D.R. (1997). Abundance of elements in the earth's crust and sea. In CRC Handbook of Physics and Chemistry, CRC Press: Boca Raton, FL, USA, p. 14.

Lifton, J. (2010). The Battle Over Rare Earth Metals, Journal of Energy Security http://www.ensec.org/index.php?option=com_content\&view=article\&id=228:the-battle-overrare-earth-metals\&catid=102:issuecontent\&Itemid $=355$

Love, B., Kleber, E.V. (1960). The Technology of Scandium, Yt trium and the Rare Earth Metals. A Literature Survey, Research Chemicals Div. of Nuclear Corp. of America: Burbank, CA, USA; Pergamon: Oxford, UK.

McGill, I. (1997). Rare earth metals. Handbook of extractive metallurgy, 3, 1695-1741.

Moran-Palacios, H., Ortega-Fernandez, F., Lopez-Castaño, R., \& Alvarez-Cabal, J. V. (2019). The Potential of Iron Ore Tailings as Secondary Deposits of Rare Earths. Applied Sciences, 9(14), 2913.

Morrison, W. M., \& Tang, R. (2012). China's rare earth industry and export regime: economic and trade implications for the United States. Congressional Research Service, http://www.fas.org/sgp/crs/row/R42510.pdf)

Porowski, A., \& Kaczor-Kurzawa, D. (2016). Pierwiastki ziem rzadkich (REE) w wodach termalnych: występowanie, pochodzenie, znaczenie i perspektywy badań w Polsce. Technika Poszukiwań Geologicznych, 55(1), 89-102.

Pourmand, A., Dauphas, N., \& Ireland, T. J. (2012). A novel extraction chromatography and MC-ICPMS technique for rapid analysis of REE, Sc and Y: Revising CI-chondrite and Post-Archean Australian Shale (PAAS) abundances. Chemical Geology, 291, 38-54.

Ryan, W. (1968). Non-Ferrous Extractive Metallurgy in the United Kingdom, The Institution of Mining and Metallurgy, London, UK.

Sabot, J.L., Maestro, P. (1995). Lanthanides, In Kirk-Othmer Encyclopedia of Chemical Technology, 4th ed., John Wiley: New York, NY, USA, Volume 14, pp. 1091-1115.

Smakowski, T., Galos, K. i Lewicka, E. red. (2015). Bilans Gospodarki Surowcami Mineralnymi Polski i Swiata 2013, Instytut Gospodarki Surowcami Mineralnymi i Energia PAN, Państwowy Instytut Geologiczny-Państwowy Instytut Badawczy, Warszawa.

Wedepohl, K. H. (1995). The composition of the continental crust. Geochimica et cosmochimica Acta, 59(7), 1217-1232.

Wyłuda, T. (2016). Cenniejsze niż złoto i diamenty- metale ziem rzadkich, https://www.edukacjagieldowa.pl/2016/09/cenniejsze-niz-zloto-diamenty-metale-ziemrzadkich/

Zamęcki, Ł. (2011). Metale ziem rzadkich-nowy instrument wpływu politycznego Chińskiej Republiki Ludowej. Stosunki Międzynarodowe, 44(3-4), 249-261.

Zhang, J., Zhao, B., \& Schreiner, B. (2016). Separation hydrometallurgy of rare earth elements (p. 259). Switzerland: Springer International Publishing.

https://sciencenotes.org/printable-periodic-table-chart/

https://www.edukacjagieldowa.pl/2016/09/cenniejsze-niz-zloto-diamenty-metale-ziem-rzadkich/

https://poltimes.pl/metale-ziem-rzadkich-strategiczne-surowce-w-rekach-chin/

http://www.fas.org/sgp/crs/row/R42510.pdf

https://independenttrader.pl/metale-ziem-rzadkich-marginalizowane-aktywo.html 
https://ecowasterecycling.wordpress.com/

http://www.marketwatch.com/story/molycorp-strikes-rare-earth-elements-in-california-2011-10-04 http://online.wsj.com/article/SB10001424052970204612504576609413994133684.html www.GISreportsonline.com

https://www.spidersweb.pl/2019/07/zapotrzebowanie-na-metale-ziem-rzadkich-elektronika-gornictwokosmiczne.html

https://klubjagiellonski.pl/2019/08/14/metale-ziem-rzadkich-oczko-w-glowie-chinskiej-republikiludowej/\#

https://forsal.pl/artykuly/ 1414979, metale-ziem-rzadkich-nowym-orezem-w-walce-chin-z-usa.html

https://www.wnp.pl/tech/chca-zaspokoic-zapotrzebowanie-na-metale-ziem-rzadkich,346568.html

Submitted:

April 14, 2020
Revised:

May 20, 2020
Accepted and published online: June 24, 2020 